How Young Adult Consumers Evaluate Diffusion Brands?

Effects of Brand Loyalty and Status Consumption

Authors:

Ian Phau*

Curtin University of Technology

Edith Cheong

Curtin University of Technology

$\underline{\text { Address for Correspondence }}$

* Ian Phau

Curtin University of Technology

The School of Marketing

GPO Box U1987

Perth, Western Australia 6845

Tel: 61-8-92664014

Fax: 61-8-92663937

Email: ian.phau@cbs.curtin.edu.au 


\title{
How Young Adult Consumers Evaluate Diffusion Brands? Effects of Brand Loyalty and Status Consumption
}

\begin{abstract}
This paper evaluates how brand loyalty may affect young status consumers' evaluation of diffusion brands for high/low involvement fashion products. In particular, the positioning strategy of the type of diffusion brand names is investigated in this study. Data were gathered through an experimental research design from 739 young status consumers studying in a large university. The findings revealed that sub-brands and nested brands with different country of origins have similar product quality and brand image evaluations compared to the parent brand. This indicates that sub-brands and nested brands may be considered by brand loyal consumers as suitable substitutes for the luxury parent brands. Contrary to literature, there is no difference in findings between high and low involvement fashion products. Implications for marketers are identified.
\end{abstract}

\section{KEYWORDS}

Brand loyalty, Brand extension, Diffusion brand, Brand image, Status consumption, Product involvement 


\section{INTRODUCTION}

Fashion houses are now internationalising their brands (Lau \& Phau 2007; Schuh 2007) and broadening their appeal to target the market of young adults through the diffusion brands (Second string, first class 2006). Armani Exchange (A|X) for Armani, CK for Calvin Klien, Miu Miu for Prada and Pink for Paul Smith are examples of diffusion brands. Also known as "second lines" they are step-down line extensions of existing luxury brands, normally less expensive than the main-line merchandise (Beaudoin, Lachance \& Robitaille 2003; Dall’Olmo Riley \& Lacroix 2003; Fernie et al. 1997; Moore, Fernie \& Burt 2000). Diffusion brands aim to establish a close connection with the parent brand as a luxury product (Moore, Fernie \& Burt 2000; Speed 1998), but at the same time offer more economical alternatives for young adults to satisfy their desire towards status consumption (Aaker 1990; Kim, Lavack \& Smith 2001; Pitta \& Katsanis 1995). While there are some researchers (such as Fernie et al., 1997; Moore, Fernie \& Burt 2000) who have examined diffusion brands, there is minimal empirical research in this area. In fact no research has examined how young status consumers evaluate diffusion brands as potential substitutes for parent brands (Fernie et al. 1997). In addition, no study has investigated if brand loyalty to the parent brand, is likely to be transferred to the diffusion brand (Kayaman and Arasli, 2007; Lau and Phau 2007). More specifically, the positioning strategies in brand naming of diffusion brands and the perceptual fit to the parent brands are particularly deficient. In light of this, the paper will attempt to fill this gap through an empirical study. The paper will first present the relevant concepts that may affect consumers' evaluation of diffusion brands by reviewing the literature on status consumption, brand loyalty, brand positioning, and product involvement. This leads to the formulation of relevant hypotheses. Next the research methodology and the analysis of the results will be presented. The paper will conclude with discussion of findings, managerial implications and future research directions.

\section{RELEVANT LITERATURE}

\section{Status Consumption}

Eastman, Goldsmith and Flynn (1999 pg 42) define status consumption as "the motivational process by which individuals strive to improve their social standing through the conspicuous consumption of consumer products that confer and symbolize status both for the individual and surrounding significant others". It has the ability to affect consumer evaluation of 
diffusion brands such as whether it is perceived by consumers to possess similar quality and brand image as compared to the parent brand, and if they are considered appropriate and adequate for status display (Eastman, Goldsmith \& Flynn 1999; Mason 1981).

Status display, was first examined by Veblen's (1899) Theory of the Leisure Class. The theory proposed that the major role of products is for invidious distinction to inspire envy in others through the display of wealth. This theory was later developed into the concept of status consumption by Mason $(1981 ; 1992)$. He suggests that individuals often consume luxury products to demonstrate personal status. Both status and conspicuous consumption have often been treated interchangeably in the literature (O'Cass \& Frost 2002). The definition reflects overlapping characteristics between the two types of consumption. Status consumption is demonstrated through the act of conspicuous consumption (i.e. the ostentatious display of wealth). On the other hand, conspicuous consumption is based on status portrayal, and that social status demonstration is a dimension of conspicuous consumption (Marcoux, Filiatrault and Cheron 1997).

Status consumption is not a recent phenomenon. There is evidence of such behaviours in the earliest societies. The economic extravagances and excesses of many individuals and social groups have been well documented (Mason 1981; Veblen 1899; 1953). It is inaccurate to assume that status products are only consumed by the rich in certain countries. According to Mason (1981), significant levels of status consumption exist in all communities in the world. This consumption behaviour still contributes significantly in shaping consumer preferences for many products, which are purchased and/or consumed in a public context (O'Cass \& Frost 2002). According to them, differences in status consumption (i.e. status versus non-status consumers) and evaluation of diffusion brands can benefit by incorporating other personality variables to understand these behaviours. The literature suggests that brand loyalty is a personality variable that could yield further research in this area (Chaudhuri 1995; Chaudhuri \& Holbrook 2001; Jacoby \& Chestnut 1978).

\section{Brand Loyalty}

According to Jacoby and Kyner (1973), brand loyalty incorporates both an attitudinal and a behavioural aspect to describe consumers' overall buying behaviour within a product class. The behavioural aspect consists of repeat purchases of the brand. The attitudinal aspect 
includes a degree of dispositional commitment towards the brand with some unique values, such as perceived quality and relevant brand image. Therefore, consumers should not be indifferent to the brand (Aaker 1991; Chaudhuri \& Holbrook 2001; Lau \& Lee 1999; Lim 1997; Oliver 1999).

In general, brand loyalty can be described as a consumer's preference to buy a particular brand name in a product class, make more frequent purchases than comparable non-loyal customers and more unlikely to switch to a competitor solely because of price(Kayaman and Arasli, 2007). It has been widely identified as a major determinant of brand equity. As the number of brand loyal consumers increases, it becomes an asset for the brand. The equity of an existing brand name can be used to introduce extension products to penetrate the market. Thus there is a major connection between brand loyalty and the practice of brand extensions (Aaker 1991; Aaker 1996; Chaudhuri 1995; Dekimpe et al. 1997; Delgado-Ballester \& Munuera-Aleman 2001; Rundle-Thiele \& Bennett 2001).

It can be argued that consumers' loyalty towards a parent brand can be transferred to a diffusion brand to yield favourable consumer evaluation. Consumers may use more of a luxury brand if they identify with the image of the brand (Chaudhuri 1995; Jacoby \& Chestnut 1978). Brand loyalty provides fewer reasons for consumers to engage in extended information search among alternatives. Consumers' trust in a brand name helps to warrant positive quality perceptions towards its existing and new products. Research has shown that consumers often use perceptions of the parent brand to evaluate a new product introduced under the same brand name (Aaker 1996; Delgado-Ballester \& Munuera-Aleman 2001; Ettenson \& Gaeth 1991; Rundle-Thiele \& Bennett 2001). However, it must be stressed that some consumers may be so loyal to a particular brand that they will not accept any other substitutes, including brand extensions (Dacin \& Smith 1994; Keller \& Aaker 1992). For non-brand loyal consumers, a diffusion brand may produce a reciprocal effect and establish synergy with the parent brand (Lau \& Phau 2007). They may accept the brand extension and promote the use of the parent brand (Balachander \& Ghose 2003; Keller \& Aaker 1992; Martinez \& De Chernatony 2004; Swaminathan, Fox \& Reddy 2001). Ultimately, the success of a brand extension is determined by the use of brand positioning to achieve perceived fit with the parent brand.

\section{Brand Positioning}


Perceived fit is a major determinant for the success of a brand extension. The perception of fit allows consumers to establish common ground between the parent brand and its diffusion brand(s). This helps to determine a desired positioning relative to the parent brand to achieve similar product quality and brand image evaluation (i.e. product category and brand image fit) (Bhat \& Reddy 2001; Bridges, Keller \& Sood 2000; Kim, Lavack \& Smith 2001; Martinez \& De Chernatony 2004; Park, Milberg \& Lawson 1991). The desired positioning of a diffusion brand can be achieved via different brand naming strategies.

Brand naming strategies are techniques to position a brand extension either closer to or further away from the parent brand. They include sub-brands, nested brands and new brands (Bhat, Kelley \& O'Donnell 1998). Sub-branding combines the use of an individual brand name adjacent to the parent brand name to form a new, composite name (e.g. "Armani Exchange” for Armani). Nested branding occurs when a new brand name is introduced by the parent brand name (e.g. Levi has “Docker’s by Levi”). A new brand occurs when a product is introduced with a new brand name (e.g. Prada has “Miu Miu”) (Aaker 2000; Bhat, Kelley \& O'Donnell 1998; Speed 1998). Sub-brands and Nested brands are likely to achieve favourable evaluation because they make use of a new name in addition to the parent brand name. This helps to transfer existing awareness, quality perceptions, brand image and associations from the parent brand to these extensions (Martinez \& De Chernatony 2004; Rio, Vazquez \& Iglesias 2001; Srinivasan \& Till 2002). When there is a good fit perceived between a parent brand and the new product, sub-branding or nested branding will be a suitable naming strategy. It is unlikely that a new brand will be evaluated favourably on the basis of the parent brand. However, if consumers perceive poor fit between the parent brand and the new product, a new brand may be the best solution (Aaker 2000; Bhat, Kelley \& O'Donnell 1998; De Chernatony 1997; Kim 2003). However, there is little prior research to guide managers on this issue (Bhat, Kelley \& O'Donnell 1998; Laforet \& Saunders 1999). When companies pursue a diffusion brand, it is also necessary to consider the use of country of origin (COO) to achieve desired positioning.

\section{Country of Origin}

$\mathbf{C O O}$ is the country where the corporate headquarter of a company marketing a product or brand is situated. Typically this is the home country for a brand (Agrawal \& Kamakura 1999; Johansson, Douglas \& Nonaka 1985; Ozsomer \& Cavusgil 1991). COO has been traditionally defined as the country of manufacture, manipulated through the 'Made in' label of the 
description of a product. It has the ability to convey quality perceptions and purchase value of a product to influence consumer evaluation (Lim \& O'Cass 2001; Okechuku 1994; Papadopoulos \& Heslop 2002; Papadopoulos et al. 1987). A product is typically designed in one country, manufactured in another, and assembled in a third, resulting in a hybrid product (Baker \& Michie 1995; Chao 1993; Han \& Terpstra 1988; Iyer \& Kalita 1997; Johansson \& Nebenzahl 1986). The proposed concept of brand origin (the country that owns the brand) is more appropriate as the distinctive COO cue. The brand origin is attached to a brand name, even if the product is not designed, manufactured or assembled in that country (Lim \& O'Cass 2001; Mort \& Duncan 2003; Samiee 1994; Thakor \& Lavack 2003). Amine and Shin (2002) propose that as long as a product is associated with a well-known and respected brand name, 'it does not matter where it is made'. This proposition is supported by Hui and Zhou (2003).

Based on the above literature, brand loyalty can be used to assess how it may affect status consumers' evaluation of diffusion brands, moderated by the different brand positioning generated from brand naming strategies and COO cues. However, the evaluation of a diffusion brand may differ depending on whether it is associated with high or low product involvement.

\section{Product Involvement}

The level of product involvement has been identified as a main determinant in the amount of decision making effort devoted to the evaluation process (Assael 1984; Hsu \& Lee 2003; Zaichkowsky 1985). This is contributed by the degree of personal relevance as it measures how consumers ascribe meanings to products (Browne \& Kaldenberg 1997). Involvement has been hypothesised that it leads to greater perception of attribute difference, product importance, and commitment of brand choice (Clark \& Russell 1978; Howard \& Sheth 1969; Zaichkowsky 1985). In the purchase decision process, the major concern is when the product is relevant, consumers are motivated to make a careful purchase decision (Goldsmith \& Emmert 1991). Purchase intention, in the context of this study, is defined as how much a consumer perceives this activity as most central, meaningful and engaging part of his or her life (O’Cass 2002). However, Laurent and Kapferer (1985) suggest that one of the antecedents of product involvement is the perceived ability of the brand to express status, 
personality or identity. If a brand has the ability to express status and/or personality, it should not matter whether the brand is associated with high or low product involvement.

LeClerc and Little (1997) have found that brand loyalty is correlated with product involvement. The general viewpoint of the literature indicates that one's involvement in a product class is interrelated with one's loyalty for a brand within that product class (Quester \& Lim 2003). However, in an earlier study, Traylor (1983) proposes that it is possible for high brand loyalty to couple with low product involvement and vice versa. This suggests that brand loyalty may not always correlate with product involvement, because involvement and loyalty are consumer-defined, rather than product-defined phenomena (Martin 1998; Traylor 1983). Quester and Lim (2003) suggest there is a lack of empirical research between product involvement and brand loyalty. This study explores the connection between both items based on consumer evaluation of diffusion brands. The literature suggests the use of product quality and brand image as indicators to evaluate diffusion brand between high and low product involvement.

\section{Evaluation Indicators}

Product quality assesses whether a product delivers benefits that consumers desire for need satisfaction (Keller 1998). A brand is meaningless unless it possesses something that is marketable for consumption. A brand should have functional and psychological attributes to portray its brand image (De Chernatony \& Dall' Olmo Riley 1998; Low \& Lamb 2000). Brand image is the perception about a brand that is reflected by the brand associations held in the consumers' memory (Aaker 1991). A luxury brand should convey a luxurious image. When fashion houses introduce diffusion brands, the extension should have similar quality and image compared to the parent brand to establish product quality and brand image fit (Bhat \& Reddy 2001; Martinez \& De Chernatony 2004; Park, Milberg \& Lawson 1991).

Based on the preceding literature review, the following hypotheses were derived, which will be assessed against status brand loyal consumers for high and low involvement fashion products:

$\mathbf{H}_{1}$ : There is no difference in (a) product quality and (b) brand image evaluation between the parent brand and its sub-brand made in the same country of origin. 
$\mathbf{H}_{2}$ : There is no difference in (a) product quality and (b) brand image evaluation between the parent brand and its nested brand made in the same country of origin.

$\mathbf{H}_{3}$ : When brands are made in the same country of origin, the parent brand has more favourable (a) product quality and (b) brand image evaluation compared to its new brand.

$\mathbf{H}_{4}$ : There is no difference in (a) product quality and (b) brand image evaluation for the parent brand and its diffusion brands made in a different country of origin.

$\mathbf{H}_{5}$ : A high involvement fashion product has greater acceptance of $\mathrm{H}_{1 \mathrm{a}}$ to $\mathrm{H}_{4 \mathrm{~b}}$ compared to a low involvement fashion product.

\section{RESEARCH METHODOLOGY}

\section{Pretest and Manipulation}

To address these hypotheses, hypothetical diffusion brands were generated from real (luxury) fashion brands via a 4 (3 brand naming strategies, and parent brand) x 2 (COO cues) research design. Two pretests preceded the main study.

Pretest 1 identified two familiar fashion brands (i.e. parent brands) by replicating Phau and Prendergast's (2000) research methodology. Forty young adults in a large university were asked to list as many (luxury) fashion brand names at the 'top of the mind' as possible. The list of brand names were compared with those used in Chung and Zaichkowsky's (1999) study, which resulted in a total of 23 fashion luxury brands. These brands were presented to 181 young adults in a large university through a self-administered questionnaire for selection. 'Gucci' and 'Armani' were shown to be the most suitable brands for this study (Cheong \& Phau 2003).

Pretest 2 replicated Zhang and Schmitt's (2001) research methodology to test fictitious brand names. First, a focus group of six young adults in a large university were asked to generate a list of potential diffusion brand names for Gucci and Armani. These brand names were presented to 12 young adults (six male and six female) and they were asked to indicate the most preferred name. Aspiration for Gucci and Touché for Armani were finally chosen as the most preferred names. They were used to formulate different diffusion brands for Gucci and Armani respectively. According to Bhat, Kelley and O'Donnell's (1998) brand naming 
strategies, these include a sub-brand, a nested brand and a new brand. They are presented in Table 1.

Insert Table 1

Each set of brands, including the parent brand and its diffusion brands (i.e. a sub-brand, a nested brand and a new brand) was combined with two COO cues to formulate the $4 \times 2$ research design. This resulted in two versions of the parent brand and six versions of diffusion brands. The two chosen COO were Italy and China. Italy was chosen as it is the country of brand origin for Gucci and Armani. It is a well-known country for fashion products, which helps to communicate positive quality perceptions for this product category (Fernie et al. 1997). In contrast, China is less known for fashion brands, but it a well-known country for manufacturing (Kaynak \& Orsay 2001). Therefore both countries have the ability to convey quality perceptions and purchase value as extrinsic cues for consumer evaluation of diffusion brands (Lim \& O'Cass 2001; Okechuku 1994). Further, each brand is attached with a price tag as price is often used to signal product quality (Brucks, Zeithaml \& Naylor 2000; Davies \& Brito 2004). There were two price levels. Prices for diffusion brands were marked $30 \%$ lower than the parent brand.

These brands were evaluated in association with a high involvement product (ready to wear fashion - trousers) and a low involvement product (fashion accessory - sunglasses) (Phau \& Prendergast 1998). Both categories are the most common fashion products for status consumption (Azuma \& Fernie 2003; Silverstein \& Fiske 2003; Tilley 2001). Trousers and sunglasses were randomly assigned to Gucci and Armani respectively with a picture generated from an online store for consumer evaluation. The identical picture of trousers and sunglasses was used for each set of parent and its diffusion brand in a questionnaire for data collection.

\section{Sampling and data Collection}

Data were collected through an experimental study of 739 young adults in a large university in Australia. Much of the brand extension research made use of student samples to evaluate extension products (e.g., Aaker \& Keller 1990; Bhat \& Reddy 2001; Van Osselaer \& Alba 2003). DelVecchio (2000) and Yavas (1994) propose that a student sample can be representative of general consumers. A student sample has relatively homogenous 
respondents. This helped to control random sources of errors and reduced the potential for Type II errors (Churchill Jr. 1995; Cook \& Campbell 1979). Further, University students of age group between 18 to 25 years (i.e. young adults) chosen for the study are the target market for diffusion brands (Beaudoin, Moore \& Goldsmith 1998; Fernie et al. 1997; O'Cass \& Frost 2002; Pecotich, Pressley \& Roth 1996). Young adults usually do not have a high disposable income, but they are interested in fashion products as they are a significant part of their lives (Flynn \& Goldsmith 1999; Lim \& O'Cass 2001; O'Cass 2000). Therefore, they are suitable individuals to consume as well as to evaluate the favourability of a diffusion brand.

A self-administered questionnaire was developed to evaluate the parent brand and its diffusion brands. Based on the $4 \times 2$ research design (for two products), the questionnaire had a total of eight versions (i.e. 2 parent and 4 diffusion brands). Only one version of the questionnaire for each product was given to each respondent for completion. Established scales to measure consumers' level of status consumption (Eastman, Goldsmith \& Flynn 1999), and brand loyalty (Lau \& Lee 1999) were adapted for use in the survey forms (See Appendix A). Consumer evaluation for each diffusion brand was measured via statements on a seven-point Likert-scale for product quality and brand image.

\section{RESULTS AND ANALYSIS}

\section{Demographics}

Female respondents constituted about 65 percent of the sample. All respondents were students between the ages of 18 to 25. Almost half was not in the workforce. Approximately 45 percent were working part-time or casual and 8 percent were working full-time. About 80 per cent had an annual income below AUD\$13,000. Only those students who have lived for at least five years in Australia were considered for the study.

\section{Scales}

Scale reliabilities for status consumption and brand loyalty were between 0.7374 and 0.7808 (see Table 2), which are deemed acceptable by Nunnally (1978). Multicollinearity is not a concern as a test through examining the variance inflation shows that it is well within the acceptable range. 
The summed scores on the status consumption scale ranged from 5 to 25, with a mean of 15.57 (Std. dev. =3.585) and a median of 16 . The summed scores on the brand loyalty scale for Gucci ranged from 4 to 20, with a mean of 9.44 (Std. dev. =3.400) and a median of 10 . The summed scores on the brand loyalty scale for Armani ranged from 6 to 30, with a mean of 14.5 (Std. dev. =4.641) and a median of 15 (see Table 3).

For the purpose of analysis, the median score was used to split the status consumption and brand loyalty scores to form status/non-status and brand/non-brand loyal consumers (see

Table 3). The median spilt has been widely used in existing research to divide the sample into two categories (e.g., Browne \& Kaldenberg 1997; Hogg \& Garrow 2003; Low \& Mohr 2000; Manrai et al. 2001; Vaidyanathan \& Aggarwal 2000; Wirtz \& Chew 2002; Yeniyurt \& Townsend 2003). Respondents with scores 16 and below on the status consumption scale were defined as non-status consumers. The remaining respondents were defined as status consumers (those with scores 17 and above on the scale). Respondents with scores 10 (15) and below on the brand loyalty scale for Gucci (Armani) were defined as non-brand loyal consumers. The remaining respondents were defined as brand loyal consumers (those with scores 11 (16) and above on the scale. Respondents with scores 16 and above on the status consumption scale and 11 (16) and above on the brand loyalty scale for Gucci (Armani) were defined as status brand loyal consumers. They were the focus of this study. Status brand loyal consumers for Gucci and Armani were selected to test the hypotheses for the high involvement fashion product (trousers) and low involvement fashion product (sunglasses) respectively.

\section{Analysis for High Involvement Fashion Product (Trousers)}

ANOVA Post-hoc Bonferroni tests revealed no significant difference in product quality evaluation when the parent brand was compared to its sub-brand, nested brand and new brand that are made in the same $\mathrm{COO}$, for China and Italy. Thus $\mathrm{H}_{1 \mathrm{a}}$ and $\mathrm{H}_{2 \mathrm{a}}$ are supported. However, $\mathrm{H}_{3 \mathrm{a}}$ is rejected because when brands are made in the same COO (both Italy and China); the parent brand did not record higher product quality evaluation as compared to its new brand.

ANOVA revealed a significant difference in brand image evaluation between the parent brand and its diffusion brands that are made in the same COO for Italy ( $F=4.278, p<.05$ ) 
and China $(\mathrm{F}=4.109, \mathrm{p}<.05)$. Post-hoc Bonferroni tests revealed no significant difference in brand image evaluation when the parent brand was compared to its sub-brand and nested brand that are made in the same COO for Italy and China. Thus hypothesis $\mathrm{H}_{1 \mathrm{~b}}$ and $\mathrm{H}_{2 \mathrm{~b}}$ are supported. However, the Post-hoc Bonferroni tests revealed that the parent brand had higher brand image evaluation compared to its new brand for that Made in China label (mean = 5.18 vs. mean $=4.05)$ at the $<.05$ level. There is no significant difference in brand image evaluation between the parent brand and new brand when the product is made in Italy. Thus $\mathrm{H}_{3 \mathrm{~b}}$ is partially supported.

T-tests revealed no significant difference in product quality evaluation for the parent brand, sub-brand and new brand between the COO of Italy and China. However, the nested brand had higher evaluation when COO cue was Italy compared to China (mean $=5.05$ vs. mean $=$ 4.32; $\mathrm{t}=2.082, \mathrm{p}<.05$ ). Thus $\mathrm{H}_{4 \mathrm{a}}$ is partially supported. Further, $\mathrm{T}$-tests revealed no significant difference in brand image evaluation for the parent brand, sub-brand, nested brand and new brand between the COO cues of Italy and China. Thus $\mathrm{H}_{4 \mathrm{~b}}$ is supported. These results are summarized in Table 3 .

Insert Table 3

\section{Analysis for Low Involvement Fashion Product (Sunglasses)}

ANOVA Post-hoc Bonferroni tests revealed no significant difference in product quality evaluation when the parent brand was compared to its sub-brand, nested brand and new brand that are made in the same COO (for both Italy and China). Thus $\mathrm{H}_{1 \mathrm{a}}$ and $\mathrm{H}_{2 \mathrm{a}}$ are supported. However, $\mathrm{H}_{3 \mathrm{a}}$ is rejected because for brands which are made in the same $\mathrm{COO}$, the parent brand did not record a higher product quality evaluation compared to its new brand. The results of $\mathrm{H}_{1 \mathrm{a}}, \mathrm{H}_{2 \mathrm{a}}$ and $\mathrm{H}_{3 \mathrm{a}}$ for the low involvement fashion product (sunglasses) are similar to those for the high involvement fashion product (trousers).

The ANOVA tests revealed no significant difference in brand image evaluation between the parent brand and its diffusion brands that are made in Italy. However, there is a significant difference in brand image evaluation between the parent brand and its diffusion brands that are made in China $(\mathrm{F}=4.009, \mathrm{p}<.05)$ (see Table 4a). Post-hoc Bonferroni tests revealed no significant difference in brand image evaluation when the parent brand was compared to its sub-brand and nested brand that are made in the same COO including, Italy and China. Thus 
hypothesis $\mathrm{H}_{1 \mathrm{~b}}$ and $\mathrm{H}_{2 \mathrm{~b}}$ are supported. Similarly, the Post-hoc Bonferroni tests revealed that when brands are made in the same COO, including Italy and China, the parent brand did not record a higher brand image evaluation compared to the new brand. Thus $\mathrm{H}_{3 \mathrm{~b}}$ is rejected.

T-tests revealed no significant difference in product quality evaluation for the parent brand and sub-brand between the COO cues of Italy and China. However, the nested brand and new brand had higher product quality evaluation when the COO cue was Italy compared to China $($ mean $=5.15$ vs. mean $=4.40, \mathrm{t}=2.067, \mathrm{p}<.05 ;$ mean $=5.13$ vs. mean $=4.33, \mathrm{t}=2.002, \mathrm{p}$ $<.05$ respectively). Thus $\mathrm{H}_{4 \mathrm{a}}$ is partially supported.

Further, the T-tests revealed no significant difference in brand image evaluation for the parent brand, sub-brand and nested brand between the COO cues of Italy and China. However, the new brand had higher brand image evaluation when the COO was Italy compared to China (mean $=5.04$ vs. mean $=3.96, \mathrm{t}=2.472, \mathrm{p}<.05$ ). Thus $\mathrm{H}_{4 \mathrm{~b}}$ is partially supported. The results only partially supported the proposition (i.e. $\mathrm{H}_{4 \mathrm{a}}$ and $\mathrm{H}_{4 \mathrm{~b}}$ ) that the difference between $\mathrm{COO}$ (i.e. 'Made in') cues does not affect status brand loyal consumers' evaluation of the parent brand and its diffusion brands. The COO effect is particularly evident for the new brand. The results are summarized in Table 4.

Insert Table 4

\section{Analysis for High vs. Low Involvement Fashion Product}

The results of $\mathrm{H}_{5}$ were generated based on the comparison of results from $\mathrm{H}_{1 \mathrm{a}}$ to $\mathrm{H}_{4 \mathrm{~b}}$ between the high and low involvement fashion product. The above results do not support that there is a greater acceptance of $\mathrm{H}_{1}$ to $\mathrm{H}_{4}$ for the high involvement fashion product (trousers) compared to the low involvement fashion product (sunglasses). Thus $\mathrm{H}_{5}$ is rejected.

\section{DISCUSSION AND CONCLUDING COMMENTS}

The results suggest that sub-brands and nested brands have similar product quality and brand image evaluation compared to the parent brand. Based on the results, a sub-brand and a nested brand have each demonstrated product quality fit and brand image fit with the parent brand (Bhat \& Reddy 2001; Kim 2003; Martinez \& De Chernatony 2004; Park, Milberg \& Lawson 1991). These perceptions of fit allow young status brand loyal consumers to use a 
sub-brand and a nested brand as substitutes for the parent brand. Both of these diffusion brands carry the name of the parent brand (Aaker 2000; Bhat, Kelley \& O'Donnell 1998; Kirmani, Sood \& Bridges 1999). The ownership of a sub-brand and/or a nested brand still reflects consumers' preference to buy products from the parent brand name (DelgadoBallester \& Munuera-Aleman 2001) and for the consumers to use these diffusion brands for status display (Eastman, Goldsmith \& Flynn 1999; Mason 1981; Veblen 1899) and express their loyalty towards the parent brand (Chaudhuri 1995; Jacoby 1971).

The results suggest declining importance towards COO (i.e. 'Made in') as an information cue to assist consumer evaluation of a diffusion brand. A product is often designed, manufactured and assembled in multiple countries. The brand origin seems be more important in reflecting the quality and image of the brand. This coincides with much of the literature (Ammonini, Keogh \& Sweeney 1998; Lim \& O'Cass 2001; Mort \& Duncan 2003; Thakor \& Kohli 1996; Thakor \& Lavack 2003). The results also suggest that the impact of a COO cue is minimal when it is combined with other information cues. A brand name is more effective in communicating the image and quality perceptions of a diffusion brand. This supports Amine and Shin's (2002) proposition that 'as long as it is brand $X$, it does not matter where it is made'.

Overall, the results revealed similar findings for the high and low involvement fashion products. As long as each product is marketed under a desirable (diffusion) brand name, they are both accepted for status display and the expression of their brand loyalty. Similar findings are obtained between the high and low involvement fashion products (Lamb, Hair \& McDaniel 2004; Laurent \& Kapferer 1985). This contradicts previous research in that consumers engage in higher evaluative effort for a high compared to a low involvement product, leading to different consumer evaluation (Goldsmith \& Emmert 1991; Hsu \& Lee 2003; Zaichkowsky 1985). In this study, the importance of status display and the expression of one's loyalty override product involvement. Young status brand loyal consumers are likely to place greater value on diffusion brands that reflect the image of their parent brands (Eastman, Goldsmith \& Flynn 1999; Goldsmith, Moore \& Beaudoin 1999; Jacoby \& Kyner 1973; Mason 1981; O'Cass \& Frost 2002; Veblen 1899). Further, this result supports Traylor's (1983) proposition that it is possible for brand loyalty to occur with low product involvements in that they are consumer-defined rather than product-defined phenomena (Martin 1998; Traylor 1983). 
In the present market, a diffusion brand (a step down line extensions) is widely used by fashion houses to internationalise their brands and broaden their appeal to the younger middle market (Fernie et al. 1997). However, there is little prior research to guide managers on the use of appropriate brand naming strategies to establish diffusion brands by capitalising on existing brand loyalty. This study examined how young status brand loyal consumers evaluate different diffusion brands. Sub-brands and nested brands should be targeted towards young status brand loyal consumers for status display and to express their loyalty towards an existing brand. From the consumers' perspective, diffusion brands still allow the consumers to exercise their preference to buy a product of a particular brand name (Aaker 1996; Chaudhuri 1995; Jacoby \& Kyner 1973). Fashion houses should capitalise on this preference and trust in the brand name to encourage young status brand loyal consumers to purchase a sub-brand and/or a nested brand as a substitute for the parent brand (Delgado-Ballester \& Munuera-Aleman 2001; Ettenson \& Gaeth 1991).

Further, young adults may not be able to afford the premium prices of parent brand products. Diffusion brands are less expensive compared to those of the parent brand. They should be more affordable for the young middle market. This allows young status consumers to experience the ownership of a (luxury) fashion brand at a lower cost (Fernie et al. 1997). Fashion houses should promote a diffusion brand product to young adults by emphasising the existing quality perceptions, awareness, brand image and associations of the parent brand to reduce marketing expenditure on the initial promotion of the diffusion brand product (Aaker 1990; Dacin \& Smith 1994; Klink \& Smith 2001; Yoo \& Donthu 2001).

Young status brand loyal consumers may progress to the use of the parent brand in the future. Fashion houses may use a sub-brand and/or a nested brand to create a reciprocal effect towards the parent brand to prolong and revitalise the life of a brand (Balachander \& Ghose 2003; Jun, Mazumdar \& Raj 1999; Keller \& Aaker 1992; Swaminathan, Fox \& Reddy 2001). Moreover, sub-brands and nested brands are accepted by young status brand loyal consumers regardless of country of origin or product involvement. Therefore, it is more important to emphasise the country of brand origin in marketing strategy to reflect quality perceptions, and the ownership of the brand name rather than product involvement to signify status. 
Based on the results of the study, it is not advisable to promote a new brand as a substitute for the parent brand. However, a new brand can be developed into a brand of its own. Under certain circumstances (such as testing a new market or a new concept), it allows fashion houses to distant any parent brand associations without affecting the existing brand image. This also minimises the importance of perceived fit between the parent and diffusion brand (Bhat, Kelley \& O'Donnell 1998; Laforet \& Saunders 1999). However, a new brand requires a substantial amount of time and financial resources to achieve the same level of recognition and potential trial compared to a sub-brand and/or a nested brand. Therefore, a new brand may be treated as a future investment for fashion houses to develop a house of brands to target different segments of the market (Aaker \& Keller 1990; Dacin \& Smith 1994; Martinez \& De Chernatony 2004; Yoo \& Donthu 2001).

This paper may be limited by the use of only two brands and product categories of fashion products. It is also limited by using student samples in one Australian university. Though acculturation effects are assumed to have taken place through the use of residents who have been here for more than seven years as a control, some residents may be more resilient in holding to their own cultural values or practices. Further, perceptions from young consumers are sought instead of actual purchases or purchase intention. Though every effort has been made to elicit "perceptions" in this study, their limited purchasing power might taint some of the responses in the study of luxury brands.

As such, there are some future directions that can be considered. Research can explore how consumers evaluate different diffusion brands via multi-national sampling to establish crossnational validity (Malhotra, Agarwal \& Peterson 1996; Steenkamp \& Baumgartner 1998). In addition, there are other personality variables or external factors which may affect the consumer evaluation of a diffusion brand. Counterfeits are becoming readily available in Asia, and consumers may be confused about the difference between a diffusion brand and a counterfeit brand. Future research can assess how the issue of counterfeits may affect consumers' evaluation of diffusion brands (Ang et al. 2001; Gross \& Shapiro 1988; Tom et al. 1998; Wilke \& Zaichkowsky 1999). Further, this research examined different diffusion brands from a consumer rather than an organizational perspective. It is also important to investigate whether a diffusion brand may cannibalise on the sales of the parent brand (Lomax et al. 1997; Reddy, Holak \& Bhat 1994). 


\section{REFERENCES}

Aaker, D. A. 1990, 'Brand Extensions: The Good, the Bad, and the Ugly', Sloan Management Review, pp. 47-56.

Aaker, D. A. 1991, Managing Brand Equity, Free Press, New York.

Aaker, D. A. 1996, Building Strong Brands, The Free Press, New York.

Aaker, D. A. 2000, Brand Leadership, Free Press, New York.

Aaker, D. A. \& Keller, D. L. 1990, 'Consumer Evaluations of Brand Extensions', Journal of Marketing, vol. 54, pp. 27-41.

Agrawal, J. \& Kamakura, W. A. 1999, 'Country of Origin: A Competitive Advantage?' International Journal of Research in Marketing, vol. 16, pp. 255-267.

Amine, L. S. \& Shin, S.-H. 2002, 'A Comparison of Consumer Nationality as a Determinant of COO Preferences', Multinational Business Review, vol. 10, no. 1, pp. 45-53.

Ammonini, C., Keogh, J. \& Sweeney, J. C. 1998, 'The Dual Nature of Country-of-Origin Effects - A Study of Australian Consumers' Evaluations', Australasian Marketing Journal, vol. 6, no. 2, pp. 13-27.

Assael, H. 1984, Consumer Behavior and Marketing Action, Kent, Boston.

Azuma, N. \& Fernie, J. 2003, 'Fashion in the Globalized World and the Role of Virtual Networks in Intrinsic Fashion Design', Journal of Fashion Marketing and Management, vol. 7, no. 4, pp. 413-427.

Baker, M. J. \& Michie, J. 1995, 'Product Country Images: Perceptions of Asian Cars', In Working Paper Series No. 95/3, Department of Marketing, University of Strathclyde. 
Balachander, S. \& Ghose, S. 2003, 'Reciprocal Spillover Effects: A Strategic Benefit of Brand Extensions', Journal of Marketing, vol. 67, no. January, pp. 4-13.

Beaudoin, P., Lachance, M. J. \& Robitaille, J. 2003, 'Fashion Innovativeness, Fashion Diffusion and Brand Sensitivity Among Adolescents', Journal of Fashion Marketing and Management, vol. 7, no. 1, pp. 23 - 30.

Beaudoin, P., Moore, M. A. \& Goldsmith, R. E. 1998, 'Young Fashion Leader's and Followers' Attitudes Towards American and Imported Apparel', Journal of Product and Brand Management, vol. 7, no. 3, pp. 193-207.

Bhat, S., Kelley, G. E. \& O'Donnell, K. A. 1998, 'An Investigation of Consumer Reactions to the Use of Different Brand Names', Journal of Product and Brand Management, vol. 7, no. 1, pp. 41-50.

Bhat, S. \& Reddy, S. K. 2001, 'The Impact of Parent Brand Attribute Associations and Affect on Brand Extension Evaluation', Journal of Business Research, vol. 53, pp. 111-122.

Bridges, S., Keller, D. L. \& Sood, S. 2000, 'Communication Strategies for Brand Extensions: Enhancing Perceived Fit by Establishing Explanatory Links', Journal of Advertising, vol. 29, no. 4, pp. 1-11.

Browne, B. A. \& Kaldenberg, D. O. 1997, 'Conceptualizing Self-Monitoring: Links to Materialism and Product Involvement', Journal of Consumer Marketing, vol. 14, no. 1, pp. 31-44.

Brucks, M., Zeithaml, V. A. a. \& Naylor, G. 2000, 'Price and Brand Name as Indicators of Quality Dimensions for Consumer Durables', Academy of Marketing Science, vol. 28, no. 3, pp. 359-374.

Chao, P. 1993, 'Partitioning Country of Origin Effects: Consumer Evaluations of a Hybrid Product', Journal of International Business Studies, vol. Second Quarter, pp. 291-305. 
Chaudhuri, A. 1995, 'Brand Equity or Double Jeopardy?' Journal of Product and Brand Management, vol. 4, no. 1, pp. 26-32.

Chaudhuri, A. \& Holbrook, M. B. 2001, 'The Chain Of Effects from Brand Trust and Brand Affect to Brand Performance: The Role of Brand Loyalty', Journal of Marketing, vol. 65, no. April, pp. 81-93.

Cheong, E. N.-S. \& Phau, I. 2003, 'Status Consumption Towards Consumers' Knowledge of Luxury Brands: Awareness, Purchase, Dream Value and Dislike', in Chartered Institute of Marketing Conference, Sydney.

Chung, A. \& Zaichkowsky, J. L. 1999, 'Understanding Luxury Brand in Hong Kong', in ACR European Conference.

Churchill. Jr, G. A. 1995, Marketing Research Methodological Foundation, The Dryden Press, Forth Worth.

Clark, K. \& Russell, W. B. 1978, 'The Effects of Product Involvement and Task Definition on Anticipated Consumer Effort', in H. K. Hunt \& A. Arbor, (eds.), Advances In Consumer Research, vol. 5, MI: Association for Consumer Research, pp. 313-318.

Cook, T. D. \& Campbell, D., T. 1979, Quasi-Experimentation: Design and Analysis Issues for Field, Houghton Mifflin Co, Boston.

Dall’Olmo Riley, F. \& Lacroix, C. 2003, 'Luxury Branding on the Internet: Lost Opportunity or Impossibility?', Marketing Intelligence \& Planning, vol. 21, no. 2, pp. 96 - 104.

Dacin, P. A. \& Smith, D. C. 1994, 'The Effect of Brand Portfolio Characteristics on Consumer Evaluations of Brand Extensions', Journal of Marketing Research, vol. 31, pp. 229-242. 
Davies, G. \& Brito, E. 2004, 'Price and Quality Competition Between Brands and Own Brands: A Value System Perspective', European Journal of Marketing, vol. 38, no. 1/2, pp. 30-55.

De Chernatony, L. 1997, 'Integrating Brand Building Using Brand Taxonomies', Journal of Product and Brand Management, vol. 6, no. 1, pp. 56-63.

De Chernatony, L. \& Dall' Olmo Riley, F. 1998, 'Defining a "Brand": Beyond The Literature With Experts' Interpretations', Journal of Marketing Management, vol. 14, pp. 417443.

Dekimpe, M. G., Steenkamp, J. E. M., Mellens, M. \& Abeele, P. V. 1997, 'Decline and Variability in Brand Loyalty', International Journal of Research in Marketing, vol. 5, no. 14 , pp. 405-420.

Delgado-Ballester, E. \& Munuera-Aleman, J. L. 2001, 'Brand Trust in the Context of Consumer Loyalty', European Journal of Marketing, vol. 35, no. 11/12, pp. 12381258.

DelVecchio, D. 2000, 'Moving Beyond Fit: the Role of Brand Portfolio Characteristics in Consumer Evaluations of Brand Reliability', Journal of Product and Brand Management, vol. 9, no. 7, pp. 457-471.

Eastman, J. K., Goldsmith, R. E. \& Flynn, L. R. 1999, 'Status Consumption in Consumer Behavior: Scale Development and Validation', Journal of Marketing Theory and Practice, vol. Summer, pp. 41-52.

Ettenson, R. \& Gaeth, G. 1991, 'Commentary: Consumers' Perception of Hybrid Bi-National Products', Journal of Consumer Marketing, vol. 8, no. 4, pp. 13-18.

Fernie, J., Moore, C., Lawrie, A. \& Hallsworth, A. 1997, 'The Internationalization of the High Fashion Brand: the Case of Central London', Journal of Product and Brand Management, vol. 6, no. 3, pp. 151-162. 
Flynn, L. \& Goldsmith, R. E. 1999, 'A Short, Reliable Measure of Subjective Knowledge', Journal of Business Research, vol. 46, pp. 57-66.

Goldsmith, R. E. \& Emmert, J. 1991, 'Measuring Product Category Involvement: A Multitrait-Multimethod Study', Journal of Business Research, vol. 23, pp. 363-371.

Goldsmith, R. E., Moore, M. A. \& Beaudoin, P. 1999, 'Fashion Innovativeness and SelfConcept: A Replication', Journal of Product and Brand Management, vol. 8, no. 1, pp. 7-18.

Gross, G. M. \& Shapiro, C. 1988, 'Counterfeit-Product Trade', The American Economic Review, vol. March, pp. 59-75.

Han, M. C. \& Terpstra, V. 1988, 'Country of Origin Effects for Uni-National and Bi-National products', Journal of International Business Studies, vol. 19, no. Summer, pp. 235255.

Hogg, M. K. \& Garrow, T. 2003, 'Gender, Identity and the Consumption of Advertising', Qualitative Market Research: An International Journal, vol. 3, pp. 160-174.

Howard, J. A. \& Sheth, J. N. 1969, The Theory of Buyer Behavior, John Wiley, New York.

Hsu, T.-H. \& Lee, M. 2003, 'The Refinement of Measuring Consumer Involvement - An Empirical Study', Competitive Review, vol. 13, no. 1, pp. 56-65.

Hui, M. K. \& Zhou, L. 2003, 'Country-of-Manufacture Effects for Known Brands', European Journal of Marketing, vol. 37, no. 1/2, pp. 133-153.

Iyer, G. R. \& Kalita, J. K. 1997, 'The Impact of Country-of-Origin and Country-ofManufacture Cues on Consumer Perceptions of Quality and Value', Journal of Global Marketing, vol. 11, no. 1, pp. 7-26.

Jacoby, J. 1971, 'A Model of Multi-brand Loyalty', Journal of Advertising Research, vol. June, pp. 25-31. 
Jacoby, J. \& Chestnut, R. 1978, Brand Loyalty Measurement and Management, John Wiley \& Sons, New York.

Jacoby, J. \& Kyner, D. B. 1973, 'Brand Loyalty Versus Repeat Purchasing', Journal of Marketing Research, vol. 10, no. February, pp. 1-9.

Johansson, J. K., Douglas, S. P. \& Nonaka, I. 1985, 'Assessing the Impact of Country of Origin on Product Evaluation: A New Methodological Perspective', Journal of Marketing Research, vol. 22, pp. 388-396.

Johansson, J. K. \& Nebenzahl, I. D. 1986, 'Multinational Production: Effect on Brand Value', Journal of International Business Studies, vol. 17, no. 3, pp. 101-126.

Jun, S. Y., Mazumdar, T. \& Raj, S. P. 1999, 'Effects of Technological Hierarchy on Brand Extension Evaluations', Journal of Business Research, vol. 46, pp. 31-43.

Kaynak, E. \& Orsay, K. 2001, 'Country-of-Origin Evaluations: Hong Kong Consumers' Perception of Foreign Products After the Chinese Takeover of 1997', International Journal of Advertising, vol. 20, pp. 117-138.

Keller, D. L. \& Aaker, D. A. 1992, 'The Effects of Sequential Introduction of Brand Extensions', Journal of Marketing Research, vol. 29, pp. 35-50.

Keller, K. L. 1998, Strategic Brand Management: Building, Measuring, and Managing Brand Equity, Prentice Hall, New Jersey.

Kim, C. K., Lavack, A. M. \& Smith, M. 2001, 'Consumer Evaluation of Vertical Brand Extensions and Core Brands', Journal of Business Research, vol. 52, pp. 211-222.

Kim, J. Y. 2003, 'Communication Message Strategies for Brand Extensions', Journal of Product and Brand Management, vol. 12, no. 7, pp. 462-476. 
Kirmani, A., Sood, S. \& Bridges, S. 1999, 'The Ownership Effect in Consumer Responses to Brand Line Stretches', Journal of Marketing, vol. 63, no. 1, pp. 88-101.

Klink, R. R. \& Smith, D. C. 2001, 'Threats of the External Validity of Brand Extension Research', Journal of Marketing Research, vol. 38, no. 3, pp. 326-335.

Laforet, S. \& Saunders, J. 1999, 'Managing Brand Portfolios: Why Leaders Do What They Do', Journal of Advertising Research, pp. 51-64.

Lamb, C. W., Hair, J. F. \& McDaniel, C. 2004, Marketing, South-Western College Publishing, Cincinnati, Ohio.

Lau, G. T. \& Lee, S. H. 1999, 'Consumers' Trust in a Brand and the Link to Brand Loyalty', Journal of Market Focused Management, vol. 4, pp. 341-370.

Lau, K. C. \& Phau, I. 2007, ' Extending Symbolic Brands Using Their Personality: Examining Antecedents and Implications Towards Brand Image Fit and Brand Dilution', Psychology \& Marketing, vol. 24, no. 5, pp. 421 - 444.

Laurent, G. \& Kapferer, J.-N. 1985, 'Measuring Consumer Involvement Profiles', Journal of Marketing Research, vol. 22, no. February, pp. 41-53.

LeClerc, F. \& Little, J. D. C. 1997, 'Can Advertising Copy Make FSI Coupons More Effective', Journal of Marketing Research, vol. 34, no. November, pp. 473-484.

Lim, K. \& O'Cass, A. 2001, 'Consumer Brand Classifications: An Assessment of Culture-ofOrigin versus Country-of-Origin', Journal of Product and Brand Management, vol. 10, no. 2, pp. 120-136.

Lim, K. S. 1997, 'Brand Loyalty and Situational Effects: An Interactionist Perspective', Journal of International Consumer Marketing, vol. 9, no. 4, pp. 95-115.

Lomax, W., Hammond, K., East, R. \& Clemente, M. 1997, 'The Measurement of Cannibalization', Journal of Product and Brand Management, vol. 6, no. 1, pp. 27-39. 
Low, G. S. \& Lamb, C. W. J. 2000, 'The Measurement and Dimensionality of Brand Associations', Journal of Product and Brand Management, vol. 9, no. 6, pp. 350-368.

Low, G. S. \& Mohr, J. J. 2000, 'Advertising vs Sales Promotion: A Brand Management Perspective', Journal of Product and Brand Management, vol. 9, no. 6, pp. 389-414.

Malhotra, N. K., Agarwal, J. \& Peterson, M. 1996, 'Methodological Issues in Cross-Cultural Marketing Research: A State of the Art Review', International Marketing Review, vol. 13, no. 5, pp. 7-43.

Manrai, L. A., Lascu, D.-N., Manrai, A. K. \& Babb, H. W. 2001, 'A Cross-Cultural Comparison of Style in Eastern European Emerging Markets', International Marketing Review, vol. 18, no. 3, pp. 270-285.

Marcoux, J. S., Filiatrault, P. \& Cheron, E. 1997, 'The Attitudes Underlying Preferences of Young Urban Educated Polish Consumers Towards Products Made in Western Countries', Journal of International Consumer Marketing, vol. 9, no. 4, pp. 5-29.

Martin, C. L. 1998, 'Relationship Marketing: A High Involvement Product Attribute Approach', Journal of Marketing Research, vol. 5, pp. 13-19.

Martinez, E. \& De Chernatony, L. 2004, 'The Effect of Brand Extension Strategies Upon Brand Image', Journal of Consumer Marketing, vol. 21, no. 1, pp. 39-50.

Mason, R. S. 1981, Conspicuous Consumption: A Study of Exceptional Consumer Behaviour, Gower Publishing Company Limited, England.

Mason, R. S. 1992, Modelling the Demand for Status Goods, Working Paper, University of Sanford.

Moore, C. M., Fernie, J. \& Burt, S. 2000, 'Brands Without Boundaries: The Internationalisation of the Designer Retailer's Brand', European Journal of Marketing, vol. 34, no. 8, pp. 919 - 937. 
Mort, G. S. \& Duncan, M. 2003, "'Own by...": Country of Origin's New Cue', Journal of International Consumer Marketing, vol. 15, no. 3, pp. 49- 69.

Nunnally, J. 1978, Psychometric Theory, 2nd Edition edn, McGraw-Hill, New York.

O'Cass, A. 2000, 'A Psychometric Evaluation of a Revised Version of the Lennox and Wolfe Revised Self-Monitoring Scale', Psychology \& Marketing, vol. 17, no. 5, pp. 397-419.

O'Cass, A. \& Frost, H. 2002, 'Status Brands: Examining the Effects of Non-Product-Related Brand Associations on Status and Conspicuous Consumption', Journal of Product and Brand Management, vol. 11, no. 2, pp. 67-88.

Okechuku, C. 1994, 'The Importance of Product Country of Origin: A Conjoint Analysis of the United States, Canada, Germany and the Netherlands', European Journal of Marketing, vol. 28, no. 1, pp. 5-19.

Oliver, R. L. 1999, 'Whence Consumer Loyalty?' Journal of Marketing, vol. 63, no. Special Issue, pp. 33-44.

Ozsomer, A. \& Cavusgil, T. S. 1991, 'Country-of-Origin Effects on Product Evaluations: A Sequel to Bilkey and Nes Review', in M. Gilly, T. F. Dwyer, T. W. Leigh, A. J. Dubinsky, M. L. Richins, D. Curry, A. Venkatesh, M. Kotabe, R. R. Kholakis \& G. E. Hills, (eds.), American Marketing Association, IL, Chicago, pp. 269-277.

Papadopoulos, N. G. \& Heslop, L. A. 2002, 'Country Equity and Country Branding: Problems and Prospects', Journal of Brand Management, vol. 9, no. 4-5, pp. 294-314.

Papadopoulos, N. G., Heslop, L. A., Graby, F. \& Avlonitis, G. 1987, Does Country of Origin Matter? Some Findings From a Cross-National Study of Consumer Views About Foreign Product, Marketing Science Institute, Cambridge, MA. 
Park, C. W., Milberg, S. \& Lawson, R. 1991, 'Evaluation of Brand Extensions: The Role of Product Feature Similarity and Brand Concept Consistency', Journal of Consumer Research, vol. 18, pp. 185-193.

Pecotich, A., Pressley, M. \& Roth, D. 1996, 'The Impact of Country-of-Origin in the Retail Service Context', Journal of Retailing and Consumer Services, vol. 3, no. 4, pp. 21324.

Phau, I. \& Poon, S. M. 2000, 'Factors Influencing the Types of Products and Service Purchase Over the Internet', Internet Research: Electronic Networking Applications and Policy, vol. 10, no. 2, pp. 102-113.

Phau, I. \& Prendergast, G. 1998, 'How Useful is Product Involvement Classification? A Tale of 3 cities', Journal of Global Competitiveness, vol. 6, no. 2, pp. 37-46.

Phau, I. \& Prendergast, G. 2000, 'Consuming Luxury Brands: The Relevance of the Rarity Principle', Journal of Brand Management, vol. 8, no. 2, pp. 122-138.

Pitta, D. A. \& Katsanis, L. P. 1995, 'Understanding Brand Equity for Successful Brand Extension', Journal of Consumer Marketing, vol. 12, no. 4, pp. 51-64.

Quester, P. \& Lim, A. L. 2003, 'Product Involvement/Brand Loyalty: Is There a Link?' Journal of Product and Brand Management, vol. 12, no. 1, pp. 22-38.

Rao, A. R. \& Ruekert, R. W. 1994, 'Brand Alliances as Signals of Product Quality', Sloan Management Review, vol. 4, no. Fall, pp. 87-97.

Reddy, S. K., Holak, S., L. \& Bhat, S. 1994, 'To Extend of Not to Extend: Success Determinants of Line Extensions', Journal of Marketing Research, vol. 31, pp. 243262.

Rio, A. B. D., Vazquez, R. \& Iglesias, V. 2001, 'The Role of the Brand Name in Obtaining Differential Advantages', Journal of Product and Brand Management, vol. 10, no. 7, pp. 452-465. 
Rundle-Thiele, S. \& Bennett, R. 2001, 'A Brand for All Season? A Discussion of Brand Loyalty Approaches and their Applicability for Different Marketers', Journal of Product and Brand Management, vol. 10, no. 1, pp. 25-37.

Samiee, S. 1994, 'Customer Evaluation of Products in a Global Market', Journal of International Business Studies, vol. Third Quarter, pp. 579-605.

Schuh, A. 2005, 'Brand Strategies of Western MNCs as Drivers of Globalization in Central and Eastern Europe', European Journal of Marketing, vol. 41, no. 3/4, pp. 271 - 291.

'Second string, first class’ 2006, Telegraph, 3 April.

Silverstein, M. J. \& Fiske, N. 2003, 'Luxury for the Masses', Harvard Business Review, vol. April, pp. 1-10.

Speed, R. 1998, 'Choosing Between Line Extensions and Second Brands: the Case of the Australian and New Zealand Wine Industries', Journal of Product and Brand Management, vol. 7, no. 6, pp. 519-536.

Srinivasan, S. S. \& Till, B. D. 2002, 'Evaluation of Search, Experience and Credence Attributes: Role of Brand Name and Product Trial', Journal of Product and Brand Management, vol. 11, no. 7, pp. 417-431.

Steenkamp, J.-B. E. M. \& Baumgartner, H. 1998, 'Assessing Measurement Invariance in Cross-National Consumer Research', Journal of Consumer Research, vol. 25, no. June, pp. 78-90.

Swaminathan, V., Fox, R. J. \& Reddy, S. K. 2001, 'The Impact of Brand Extension Introduction on Choice', Journal of Marketing, vol. 65, pp. 1-15.

Thakor, M. \& Kohli, C. S. 1996, 'Brand Origin: Conceptualization and Review', Journal of Consumer Marketing, vol. 13, no. 3, pp. 27-42. 
Thakor, M. V. \& Lavack, A. M. 2003, 'Effect of Perceived Brand Origin Associations on Consumer Perceptions of Quality', Journal of Product and Brand Management, vol. 12, no. 6, pp. 394-407.

Tilley, R. 2001, 'How to Spend it: the World's Luxury Goods Retailers Make East Asia their New Battleground', Asia-mc, vol. January, pp. 30-33.

Tom, G., Garibaldi, B., Zeng, Y. \& Pilcher, J. 1998, 'Consumer Demand for Counterfeit Goods', Psychology \& Marketing, vol. 15, no. 5, pp. 405-421.

Traylor, M. B. 1983, 'Ego Involvement and Brand Commitment: Not Necessarily the Same', Journal of Consumer Marketing, vol. 1, no. 75-79.

Vaidyanathan, R. \& Aggarwal, P. 2000, 'Strategic Brand Alliances: Implications of Ingredient Branding for National and Private Label Brands', Journal of Product and Brand Management, vol. 9, no. 4, pp. 214-228.

Van Osselaer, S. M. J. \& Alba, J. W. 2003, 'Locus of Equity and Brand Extension', Journal of Consumer Research, vol. 29, no. 4, pp. 539-550.

Veblen, T. 1899, The Theory of the Leisure Class, Dover Publications, INC., New York.

Veblen, T. 1953, The Theory of the Leisure Class, Mentor, New York.

Wilke, R. \& Zaichkowsky, J. L. 1999, 'Brand Imitation and Its Effects on Innovations, Competition, and Brand Equity', Business Horizons, vol. November-December, pp. 918.

Wirtz, J. \& Chew, P. 2002, 'The Effects of Incentives, Deal Proneness, Satisfaction and Tie Strength on Word-of-Mouth Behaviour', International Journal of Service Industry Management, vol. 13, no. 2, pp. 141-162. 
Yavas, U. 1994, 'Research Note: Students as Subjects in Advertising and Marketing Research', International Marketing Review, vol. 11, no. 4, pp. 35-43.

Yeniyurt, S. \& Townsend, J. D. 2003, 'Does Culture Explain Acceptance of New Products in a Country? An Empirical Investigation', International Marketing Review, vol. 20, no. 4, pp. 377-396.

Yoo, B. \& Donthu, N. 2001, 'Developing and Validating a Multidimensional Consumerbased Brand Equity Scale', Journal of Business Research, vol. 52, pp. 1-14.

Zaichkowsky, J. L. 1985, 'Measuring the Involvement Construct', Journal of Consumer Research, vol. 12, pp. 341-352.

Zhang, S. \& Schmitt, B. H. 2001, 'Creating Local Brands in Multilingual International Markets', Journal of Marketing Research, vol. 38, no. August, pp. 313-325. 


\section{Table 1}

Diffusion Brands for Armani and Gucci

\begin{tabular}{|l|l|l|}
\hline Parent brand & Armani & Gucci \\
\hline Sub-Brand & Armani Touché & Gucci Aspiration \\
\hline Nested Brand & $\underline{\text { Touché by Armani }}$ & $\underline{\text { Aspiration by Gucci }}$ \\
\hline New Brand & $\underline{\text { Touché }}$ & $\underline{\text { Aspiration }}$ \\
\hline
\end{tabular}


Table 2

Reliability Analysis, Descriptives and Identification of

Status and Brand Loyal Consumers

\begin{tabular}{|c|c|c|c|c|c|c|c|}
\hline & & & & & & \multicolumn{2}{|c|}{ Group Segmentation } \\
\hline & $\begin{array}{l}\text { Alpha } \\
\text { Score }\end{array}$ & Range & Mean & $\begin{array}{l}\text { Std } \\
\text { Dev }\end{array}$ & Median & $\begin{array}{l}\text { Non-status } \\
\text { Non-Brand } \\
\text { loyal } \\
\text { consumer }\end{array}$ & $\begin{array}{l}\text { Status } \\
\text { Brand } \\
\text { loyal } \\
\text { consumers }\end{array}$ \\
\hline Status Consumption & 0.7374 & $5-25$ & 15.57 & 3.585 & 16 & $5-16$ & $17-25$ \\
\hline Brand Loyalty (Gucci) & 0.7483 & $4-20$ & 9.44 & 3.400 & 10 & $4-10$ & $11-20$ \\
\hline Brand Loyalty (Armani) & 0.7808 & $6-30$ & 14.5 & 4.641 & 15 & $6-15$ & $16-30$ \\
\hline
\end{tabular}


Table 3

T-Tests between Means of Brand Loyal Consumers: Evaluations of Parent/ Diffusion Brands between COO (Italy vs China) Cue - Trousers

\begin{tabular}{|l|l|l|l|l|l|l|l|l|}
\hline & \multicolumn{4}{|l}{ Product Quality } & \multicolumn{4}{l|}{ Brand Image } \\
\cline { 2 - 9 } & \multicolumn{2}{|l}{ Means } & \multicolumn{2}{l|}{ Means } & \multicolumn{2}{l|}{} \\
\cline { 2 - 9 } & Italy & China & t-value & Sig. & Italy & China & t-value & Sig. \\
\hline Parent brand & 4.89 & 4.32 & 1.589 & NS & 5.06 & 5.18 & -.301 & NS \\
\hline Sub-brand & 4.63 & 4.71 & -.215 & NS & 5.37 & 5.00 & .855 & NS \\
\hline Nested brand & 5.05 & 4.32 & 2.082 & $.044^{*}$ & 5.18 & 4.92 & .781 & NS \\
\hline New brand & 4.97 & 4.86 & .391 & NS & 4.15 & 4.05 & .297 & NS \\
\hline
\end{tabular}

* Significant at the .05 level 
TABLE 4

T-Tests between Means of Brand Loyal Consumers: Evaluations of Parent/ Diffusion Brands between COO (Italy vs China) Cue - Sunglasses

\begin{tabular}{|c|c|c|c|c|c|c|c|c|}
\hline & \multicolumn{4}{|c|}{ Product Quality } & \multicolumn{4}{|c|}{ Brand Image } \\
\hline & \multicolumn{2}{|c|}{ Means } & \multirow[b]{2}{*}{ t-value } & \multirow[b]{2}{*}{ Sig. } & \multicolumn{2}{|c|}{ Means } & \multirow[b]{2}{*}{ t-value } & \multirow[b]{2}{*}{ Sig. } \\
\hline & Italy & China & & & Italy & China & & \\
\hline Parent brand & 5.18 & 4.69 & 1.494 & .142 & 5.18 & 5.04 & .357 & .722 \\
\hline Sub-brand & 4.89 & 4.56 & .738 & .465 & 4.81 & 5.44 & -1.363 & .180 \\
\hline Nested brand & 5.15 & 4.40 & 2.067 & $.045 *$ & 5.38 & 5.05 & .861 & .394 \\
\hline New brand & 5.13 & 4.33 & 2.002 & $.049 *$ & 5.04 & 3.96 & 2.472 & $.017^{*}$ \\
\hline
\end{tabular}

* Significant at the .05 level 


\section{Appendix A}

\section{Brand Loyalty Scale (adapted from Lau \& Lee 1999)}

1. I intend to keep buying (the brand).

2. If another brand is having a sale, I will generally buy the other brand instead of (the brand).*

3. If (the brand) is not available in the store when I need it, I will buy it another time.

4. If (the brand) is not available in the store when I need it, I will buy it somewhere else.

5. If someone makes a negative comment about (the brand), I would defend it.

6. I would recommend (the brand) to someone who cannot decide which brand to buy in this product class.

7. I would believe a person if that person made a negative comment about (the brand).*

8. I often tell my friends how good (the brand) is.

\section{Status Consumption Scale (adapted from Eastman, Goldsmith \& Flynn 1999)}

1. I am interested in new products with status.

2. I would buy a product just because it has status.

3. I would pay more for a product if it has status.

4. The status of a product is irrelevant to me.

5. A product is more valuable to me if it has some *snob appeal 